\title{
Odysseus - Trickster and the Issue of the Compatibility of the Image of the Hero with Its Function in the Traditions of the Oral Epic
}

\author{
Karol Zieliński iD https://orcid.org/0000-0001-9518-935X \\ University of Wrocław \\ Institute of Classical, Mediterranean and Oriental Studies \\ karol.zielinski@uwr.edu.pl
}

\begin{abstract}
In the Greek epic tradition associated with the Trojan cycle, the protagonists are played by Achilles and Odysseus, two heroes with contrasting characteristics. The Homeric poems endeavor to approximate the character of Odysseus to Achilles. They cannot, however, break with his traditional image in which he represents the trickster type. Both preservation of the traditional image and its reinterpretation is typical of the oral tradition. Comparison with other traditions of the oral epic reveals a connection between the trickster character and the antagonist of the hero-protagonist. Both polarized characters represent two types of behavior assessed by the listening audience in terms of their usefulness for the survival of the community. In his readiness for sacrifice, the hero represents an altruistic attitude, positively valorized as moral behavior. The trickster's egoistic behavior moves away from moral principles, but it can also ultimately bring benefit to the whole community. Similarly to the behavior of the trickster-antagonist, that of the hero-protagonist is also ambivalent, as it brings harm to the community, which - though temporary - often takes on the dimension of a disaster.
\end{abstract}

Keywords: trickster, oral tradition, Odysseus, epic hero, Homer

Słowa kluczowe: trickster, tradycja oralna, Odyseusz, heros epicki, Homer

The idea of the paper is to present the character of Odysseus in the perspective of the fluidity of the oral tradition, a fluidity which enables the reconfiguration of the images of protagonists by way of permanent reinterpretation of their behaviors in subsequent performances. Comparative studies allow us to reconstruct a primordial opposition between a hero-protagonist and his antagonist, who very often represents features which scholars link with the trickster figure. The Homeric poems display a tendency for both 
antagonized characters to take over the features of each other. As a result, Odysseus may play the role of the hero-protagonist and resemble Achilles in his conduct, without entirely discarding elements of the trickster. What is crucial here is the relationship between the heroes and their community considering the benefits expected by the group as a result of the hero's deeds. In effect both characters, Odysseus and Achilles, turn out to be ambivalent in their conduct. Just like the gods, they can bring harm or bestow benefits upon their communities. ${ }^{1}$ To understand this complex image I propose to begin the discussion from adaptive qualities of the oral tradition.

From an adaptive point of view, the production of cultural patterns is associated with the struggle for existence. ${ }^{2}$ The significance of this element of the evolutionary process is evidenced by the role of narrative in the development of human culture, especially in oral culture, which covers an incomparably longer period than written culture in the history of mankind. Narratives in oral culture retain a certain durability, allowing us to recognize both the same story patterns and the same stories (we recognize the same story in different versions), while continually modifying them in subsequent performances according to the rules of homeostasis, the circumstances of their delivery, and the inventiveness - or rather the intentions - of the steward of the tradition: the bard or the teller of myths. Narrative, a flexible tool capable of constantly adapting to changing conditions, serves to unite a group around a tradition. This theory explains, in my opinion, the prevalence of characters such as the trickster in human cultures.

Attempts to describe the process of diffusion as a cultural phenomenon will only be theoretical, and they allow for some organization of data from various regions of the world, but they will not correspond to the reality that generates the need for the origination of this process. They will, therefore, remain a deceptive illusion. The creation of the character of the trickster in oral cultures - the shaping of his image, the attribution of certain permanent features to him - thus reflects the evaluation of attitudes adopted in those societies that condition their survival. What counts is not only the character himself and the character's actions, but also the reactions it triggers. This must mean a certain gradation of features associated with the trickster: some features must be considered as primary, others as secondary, and resulting from the various associations so largely ensuing from reactions to the behavior attributed to this character. However, the trickster figure may turn out to be merely a product of academic discourse, resulting from the fact that these controversial and ambivalent figures, occurring in many cultures in a similar role, correspond to a repeatable problem of adaptation of a group to changing circumstances.

${ }^{1}$ About the ambivalence of the Greek gods see J. Gould, Myth, Ritual Memory, and Exchange. Essays in Greek Literature and Culture, Oxford 2001, pp. 203-234.

${ }^{2}$ The question is, though, how to understand culture as a result of evolution. For the discussion on this issue, see D.S. Wilson, Darwin's Cathedral. Evolution, Religion, and the Nature of Society, ChicagoLondon 2002, pp. 31-37, whose attitude is closest to me. The article does not give me enough scope for considering the issue of group selection and the possibility of this principle functioning in human cultures. Two polarized positions are presented by R. Dawkins, The Selfish Gene, Oxford 1976 and D.S. Wilson, op. cit. 
The trickster figure is characterized by ambivalence of his actions, because it is difficult to assess whether his deeds bring about good or bad results. His "usefulness" manifests itself in actions identifying him with a cultural hero who bestows basic cultural goods upon mankind, or even with the demiurge-creator of the world. ${ }^{3}$ At the same time he seems to be very selfish and unprofitable for any human society. I propose to look at this complex problem in terms of the functioning of oral epic traditions, bearing in mind that oral tradition is prone to constant changes: individual songs and even their performances subject the traditional material to reinterpretation.

The character of the trickster can be recognized by certain traits: malice, slyness, cunning, greed and an inclination to cheat and use spells or illusion. Owing to this, on the one hand he is avoided by others as he incites hatred motivated by fear, while on the other he is the object of derision or mockery. All these reactions to the trickster's deeds mean that they are perceived as improper, and incompatible with the recognized rules of behavior. He is recognized as an individual who opposes the community and shuns it, demonstrating hatred or contempt, which can also be expressed through laughter or may be interpreted as an effort to isolate such an individual and to stigmatize what he represents. Understandably, such distancing must result from the group's adherence to other behaviors that can be explicitly or implicitly referred to in the story of the trickster. The sources of stories about this character, disseminated in various cultures, lie - in my opinion - in the axiology of communal behavior. What other end could a story serve if not to convey the models of expected and unacceptable behavior? Ethological evaluation in oral culture, however, is not diametrically opposed as good or bad. What counts is the ultimate benefit which the community derives from the behavior of individuals. The morally ambivalent conduct of epic heroes illustrates how difficult it is for a group to temper selfish needs and the behavior of individuals. Every performance of the oral epic indicates how traditional patterns of behavior should or may be adapted to the current situation. Epic heroes do not repeat such desirable patterns in their conduct because they are unable to follow common rules - very often they have to break these rules. They are individualists, although they accept the rules of the collective mentality. Hence, the oral epic cannot be perceived as didactic in a moral sense.

We might say that the people of oral cultures may seem more sincere than those of written culture because they openly admit they do not always know what kind of conduct may be beneficial to the community: paradoxically, sometimes the rejection of rules suppressing the egoism of individuals may bring good results to the community (epic heroes often - consciously or unconsciously - break a taboo, which turns out to be advantageous for the hero and for the community). ${ }^{4}$ This is because from an adaptive point of view, only actions can be evaluated, and not the motivations behind them.

\footnotetext{
${ }^{3}$ Because this volume contains an article by Prof. A. Szyjewski which discusses all the conundrums resulting from the acceptance of the term "trickster" in science, I feel it unnecessary to present the history of research on this issue.

${ }^{4}$ For example, in all hunter-gatherer societies there is a law of sharing food, especially meat, with other members of the group (see Wilson, op. cit., pp. 24-27).
} 


\section{Egoism and altruism}

In this regard, ethology refers to game theory and introduces two models of strategies that allow the individual to survive and to preserve his or her genes: ${ }^{5}$

Mathematical theory allows two broad classes of stable solution to "games" of this kind. "Always be nasty" is stable in that, if everybody else is doing it, a single nice individual cannot do better. But there is another strategy which is also stable. ("Stable" means that, once it exceeds a critical frequency in the populations, no alternative does better.) This is the strategy: "Start out being nice, and give others the benefit of the doubt. Then repay good deeds with good, but avenge bad deeds." In game theory language, this strategy, (or family of related strategies) goes under various names, including Tit-for-Tat, Retaliator and Reciprocator. It is evolutionarily stable under some conditions in the sense that, given a population dominated by reciprocators, no single nasty individual, and no single unconditionally nice individual, will do better. There are other, more complicated variants of Tit-for-Tat which can in some circumstances do better.

Richard Dawkins details four types of evolutionary altruism which could develop advantageously in small human communities: 1) kin altruism, encouraging individuals to support people with the same genes, 2) reciprocal altruism, referring to the returning of favors and giving of favors in anticipation of payback, 3) building a good reputation for altruism, which becomes more important in language-speaking societies, 4) ostentatious generosity towards others that publicizes one's dominance or superiority and establishes the hierarchical position of individuals within the group (the Potlatch Effect). These rules, according to Dawkins, shaped a system of behaviors which may be perceived as moral rules.

D.S. Wilson assesses the rejection of group selection as "evolutionary theory's wrong turn," which possessed the minds of intellectuals in the second half of the 20 th century. In his opinion, groups function like one organism not because they exclude the selfishness of individuals but because they are able to suppress their selfish behavior. Groups, especially human societies, work out mechanisms of social control to reduce or marginalize selfish behaviors of individuals and to promote altruistic behaviors supporting the survival of the group among other groups. Consequently, any behaviors that deviate from these rules or contradict them must be viewed as inappropriate or even harmful, because they would threaten the stability of the group.

Let us look at Homeric studies from this perspective. The characters of the epic are so aggressive in their relationships with each other and so focused on themselves and on defending their honor that they do not seem to notice the advantages of collective effort. Alone, they are ready to take any action and seem to be able to perform deeds which a group cannot perform; the epic story even loses sight of the group and focuses on the actions of the hero. ${ }^{7}$ Surprisingly, it was only in the 1990s that Douglas Cairns proved that in the Homeric world the good of the group is respected, that the

${ }^{5}$ Game theory was introduced to evolutionary biology by Robert Trivers.

${ }^{6}$ D.S. Wilson, op. cit., pp. $14-15$.

${ }^{7}$ H. van Wees, Greek Warfare: Myths and Realities, London 2004. Van Vees notices the illusory nature of this representation in relation to the realities of the battlefield. Of course, battles are won by groups and not by individuals. 
heroes are also driven by altruistic motives to cooperate with others, and that their behavior is guided by the principle of reciprocity, a principle that ordains mutual respect and confines the aggressive selfishness of the heroes who come under competitive pressure (who try to impose their advantage on others to defend their honor). ${ }^{8}$ It would be ridiculous to think of altruism as the cultural achievement of Homer. Therefore, Cairns' rightful conclusion should be confronted with the oral tradition from which the Iliad emerged, as well as with comparative data from other epic traditions. The Iliad cannot be conceived of in terms of nascitur of European literature: it is a product of centuries of oral epic tradition, remaining one of the multitudes of works composed in that era. On the basis of comparative data we can ascertain the way in which the lengthy oral tradition evolved.

The epic tale focuses on the actions of a hero whose task is to protect the community from which he originates and which he represents. The hero is a personification of the community's vital forces and the energy that permits it to survive. His action is salutary (by saving the group from peril, the hero determines its survival). The message sent to the heeding audience is: "We exist and we have only subsisted because this threat has been removed in this way." Of course, the number of threats and the number of heroes facing them can be proliferated in subsequent epic songs also within the same culture, the best example being the Greek tradition. However, the approach that the hero takes and the way he acts will be the same every time. The hero restores order to the world by demonstrating his strength and bravery. Eleazar Mieletinski pointed out, however, that this mode of acting was developed in the course of the evolution of a heroic story. In the earlier stage, the hero - referred to as cultural hero - does not take advantage by force but by magic or trickery, and he does not shy away from deceit and theft. However, even the action of a hero-killer often appears to be ambivalent: blindly, he unleashes his destructive power against his own kin; he is flawed by pride which often leads to a conflict with a deity and, as a result, to his demise. ${ }^{9}$ The hero works for the benefit of the community, but most often alone: sometimes he is even isolated from society or decides to alienate himself from it, and although various motivations may accompany this behavior, he exhibits a certain level of egoism which distances him from the group, and even condemns his fellow countrymen to suffering. This is

${ }^{8}$ D. Cairns, Oxford Readings in Homer's Iliad, Oxford 2001, pp. 215-216 (this is a revised version of the article published in 1993), criticizes the generally accepted view of A.W.H. Adkins (Merit and Responsibility, Oxford 1960) who based the behavioral system of Homeric warriors on the principle of competition. This is not a thorough critique of Adkins's views. A stronger attack on the researcher was carried out by H. van Wees (Status Warriors, War, Violence and Society in Homer and History, Amsterdam 1992). Cairns, however, raises the issue that is of interest to us. R. Seaford, in turn, shows how deeply the principle of reciprocity is rooted in Homer's ritual thinking (Reciprocity and Ritual, Homer and Tragedy in the Developing City-State, Oxford 1994). This problem is discussed in more detail in Reciprocity in Ancient Greece, C. Gill, N. Postlethwaite and R. Seaford (eds.), Oxford 1998.

9 E. Meletinsky, Pochodzenie eposu bohaterskiego. Wczesne formy i archaiczne zabytki, Kraków 2009: about Batradz (Narts epic) pp. 197-198, Amirani (Georgian epic) pp. 207-208, Abrskil (Abkhazian epic) and others pp. 209-211; G. Nagy, The Best of Achaeans: Concepts of the Hero in Archaic Greek Poetry, Baltimore-London 1999, pp. 289-295 shows the traditional conflict of Greek heroes with Apollo: the deity leads to the death of heroes (e.g., Achilles) and then to their apotheosis. 
best illustrated by the case of Achilles. We must remember that the Iliad known to us was not the only story where this hero acts in a sequence of "withdrawal from the fight/ defeat of the Acheans'/return to the fight/rescue of the Achaeans." We should rather assume that this is how the tradition as well as subsequent songs depicting episodes of the Trojan War typically represent the role of Thetis's son. ${ }^{10}$

A special role in the epic narrative is played by the trickster, who can act as the hero's antagonist, the most striking example of which is Baldr's conflict with Loki. However, the character of the trickster and his behavior, which deviates from heroic norm, may prove expedient for a common cause in which the hero is engaged. This means that just like the protagonist's behavior - at least in the initial phases of his "background" (he often commits many evil acts in his childhood or early adolescence, for example) - is harmful to the community in which they live, so too may the trickster's actions prove beneficial in the grand scheme of things. Both characters seem to combine elements of egoistic behavior with working for the benefit of the group. The proportions, however, definitely vary.

The group's reaction to the behavior of both characters is also different. The hero can be harangued, even castigated, but the efficacy of his deeds is beyond doubt. It is different with the trickster. As a rule, he encounters hatred and abomination of the group. Negative reactions to this character which betray an unfavorable disposition towards him can also often lead to ridicule. In confrontations with dangerous people, mockery can be the only effective way to defeat them or to neutralize their actions. Ridicule results in exclusion from the group or at least in isolation within it. Exposure to public laughter is, in certain circumstances, even more effective than a directly vocalized reprimand. Collective laughter deprives the individual, attacked by scorn, of his means of defense. The malice of a trickster can translate into him using the weapon of laughter, but more often - or perhaps, ultimately - it is he who is derided. It is through an appropriate description of the character, that is, through the presentation of his image with an emphasis on those features which are considered offensive and embarrassing according to the moral code, that one can highlight these social reactions to the attitude represented by the trickster.

In individual traditions, not all features of the trickster must be evident. In the oral tradition, a single element is a metonymy of a whole complex of meanings. ${ }^{11}$ Over

${ }^{10}$ Cf. K. Zieliński, Iliad and Its Epic Tradition. A Study in Greek Oral Tradition, Wrocław 2014, pp. 81-135, which shows the mechanism of creating individual episodes transmitted in integral oral songs and their functioning within the oral tradition. It is not a coincidence that I also draw attention to his relationship with Thetis, although it was the name of the father that was usually used in relation to the heroes. The scale of the significance of this goddess for the plot of the Iliad in relation to the oral tradition was presented by L. Slatkin, in The Power of Thetis: Allusion and Interpretation in the Iliad, Berkeley 1991. Zieliński (op. cit.) notes that Thetis each time in the tales from the Trojan cycle known to us influences the withdrawal of Achilles from the fight. Typically, the hero retreats under the influence of the oracle, which links the end of his life with the defeat of a monstrous enemy threatening the Achaeans at the moment. In the Iliad, there is another motivation for Achilles to disengage from the fight, but these motives traditionally associated with the oracles of his divine mother are taken into account and not eliminated by Homer, which is a typical feature of the compositional technique of an author within the oral tradition.

${ }^{11}$ J.M. Foley, Immanent Art: From Structure to Meaning in Traditional Oral Epic, Bloomington (IN) 1991. 
time, however, non-replicated elements may be subject to suppression, just as inactivated meanings may be lost. As a result, the trickster character may sometimes display unusual cunning and intelligence, as in the case of Loki; likewise, he may sometimes be stupid, as often is the Hare or anthropomorphic Wakdjunkaga in Winnebago stories.

For example, in the Bosnian tradition (collected by M. Parry and A.B. Lord), The Tale of Orašac is an indispensable participant in almost every journey of heroes. His appearance and behavior are unconventional and practically non-heroic. ${ }^{12}$ His antiheroism makes him a comic character. Nevertheless, as John M. Foley observes, he performs the function of a talisman that ensures the success of the expedition. The figure of Tale of Orašac is that of a courageous warrior, but this seems difficult to reconcile with his appearance and behavior. The trickster's egoism, as suggested by his quarrelsome nature $^{13}$ and which must have influenced the development of his image, was suppressed. What remained, however, was the conviction about his paradoxical merit for the heroic cause. His usefulness for further ventures also contrasts with him being called "Stupid Tale" and describing his statements as "stupid" (insulted by such a statement, Mustajbeg does not see anything wrong with Tale's insult, because it is an incentive to immediately set out on the expedition). ${ }^{14}$

The example of the figure of Tale of Orašac indicates that the image of a given character is strongly associated with his function in the oral epic. Some trickster features may be absent but his strange, unconventional look, associated with his behavior, remains. Adopting this perspective, let us look at the Homeric poems.

\section{Descriptions of heroes in the Iliad}

It is not difficult to discern the economy of character description in oral poetics. Characters are not described more fully: they reveal who they are by what they say. ${ }^{15}$ Their descriptions indicate only the function they will perform in the story. Ruth Scodel argued that depending on the amount of information given about the hero in the expo-

12 J.M. Foley, in The Singer of Tales in Performance, Bloomington-Indianapolis 1995, pp. 32-38, discusses further features of his image as contrasting with the typical heroic image in this tradition: Tale rides a mottled grey, pathologically deformed horse, without a saddle, covered only by a shepherd's coat; he carries flour in the saddlebags thrown over the horse's back, and he uses a simple twisted string as a harness.

${ }_{13}$ Tale, as Foley observes (Ibidem, p. 36), is always at odds with his mother. He also quarrels with his people in the song “The Wedding of Mustajbeg's Son Bećirbeg," performed by Halil Bajgorić (no. 6699) and analyzed by Foley. He also speaks abusively to Mustajbeg, who organizes the expedition.

${ }^{14}$ The situation is similar to the scene in the 4th book of the Iliad (IV 370-418) where Agamemnon's rebuke was accepted by Diomedes because it is the king's right to use blame in order to spur warriors to fight, as was rightly suggested to me by an anonymous reviewer. More generally, "good" advice is that which is supposed to lead to the conquest of Troy, in contrast with "bad" advice that suggests an escape (cf. M. Schofield, Euboulia in the Iliad, "Classical Quarterly" 1986, vol. 36, pp. 6-31.

15 J. Griffin, The Speeches, [in:] The Cambridge Companion to Homer, R. Fowler (ed.), Cambridge 2004, pp. 156-167. More about the Homeric characterization of heroes see J. Griffin, Homer on Life and Death, Oxford 1980, pp. 50-80. 
sition one can judge whether the character was familiar to the public, and so whether it was part of the tradition or not. ${ }^{16} \mathrm{I}$ cannot completely agree with this statement: a fairly accurate description of Nestor (I 247-252) would then suggest that this character is little known or quite new in the tradition, while there are many signs that it was exactly the opposite. Homer introduces this character with an indication of his function as the wisest adviser, which is important at the moment when he tries to mediate between Achilles and Agamemnon, who were at odds. The recipient gets a hint of how to perceive this character (even if it is only a reminder of his typical role in the epic), and the illusory hope that this wise adviser of the Achaeans will be able to remedy the nascent conflict. ${ }^{17}$

In essence, the hero's appearance seems irrelevant. A unique detail of Achilles' appearance is mentioned only when he is offended by Agamemnon: he then considers in

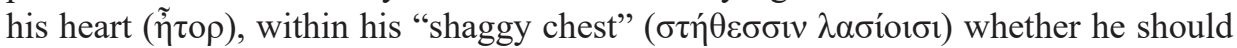
kill him (I 188-189). However, it is difficult to think about this detail as some specific feature of this hero. This epithet rather serves to emphasize the hero's masculine strength, which is usually associated with facial hair. ${ }^{18}$ Homer undoubtedly brings up the manly hair on Achilles' chest because in order to present him as a youngster who does not yet have facial hair, which is a typical description of a hero as a young man during the initiation period, he had to shift the emphasis on his masculinity to a different place on his body. ${ }^{19}$ This is not an idiosyncratic image of a hero, but typical. For comparison, let us look at the song The Wedding of Smailagić Meho performed by Avdo Medjedović, where the main character arrives at Vukašin with his ensign:

It was two hours before sunset when the wedding guests arrived before the dwelling of Vukašin, the village elder, and their family's best householder. Vukašin and his spouse were both at home; when they saw Hadji's son on his winged chestnut horse all submerged as he was in pure gold, he shone like the moon. His forged saber glided over his horse's side like a serpent around a dry thistle. The steed spread his two jaws. Were you to cast into it a Bulgarian cloak, you would not fill his gaping jaws. One would say and swear that it was an imperial field marshal upon the horse; his trappings were better than a field marshal's. Behind him rode Osman on his gray horse as though on a slender mountain spirit. He, too, was one of the mightiest heroes in this fair world. His raiment was a bit different from that of Mehmed, but his horse was mighty beyond reckoning; the horse was mighty and mighty was Osman.

Vukašin recognized them and spoke thus to his beloved spouse:

${ }^{16}$ R. Scodel, Listening to Homer: Tradition, Narrative, and Audience, Ann Arbor (MI) 2002, pp. 90-123.

${ }_{17}$ The singer plays a game with the recipient to attract his or her attention with alternating moods of horror and relief, cf. K. Zieliński, op. cit., pp. 318-334.

${ }_{18}$ G.S. Kirk, The Iliad: A Commentary, vol. I: books 1-4, Cambridge 1985, p. 73 interprets this differently: "the description of his internal struggle is made more graphic, by the addition that it took place within his 'shaggy chest'."

${ }_{19}$ The Homeric epic clearly distances itself from emphasizing masculinity by describing secondary sexual characteristics. On the perception of the human body as a carrier of information, as a specific map of the system of beliefs and social relations in illiterate societies, see M. Douglas, Purity and Danger. An Analysis of Concepts of Pollution and Taboo, London-New York 2001, esp. pp. 115-129. 
"Do you see those two noble lords in golden garments, with gilt imperial caps upon their heads, gilt caps and gilt plumes, astride their richly caparisoned horses?" When his love heard Vukašin she said to her husband: "Vukašin, my dear master, what is this rare wonder? Never before have I seen such dragons on such richly caparisoned steeds. Glorious is that youth. Blessed is the mother who bore him, and the sister who swears by him, but most blest is his true love because she knows his caress upon the couch. And that mighty one upon the gray steed! Mighty is he and awe-inspiring. O my husband, I pray you, as my own spouse, what is that he carries in his teeth? It looks like an unskinned black lamb with legs hanging over his chest." Then Vukašin addressed his love: "My dear one, it is not a lamb in his teeth, it is the moustache of that hero, Hadji Smailaga, the alaybey of Kanidza." ${ }^{20}$

All elements of the description are stereotypical and may refer to different heroes; the employment and even accumulation of these motifs serves to stimulate the reception of the listeners, who are supposed to become convinced of the magnificence of the heroes.

In the Iliad, the standard depictions of epic heroes are not presented so simply. Their behavior is often ambiguous in assessment (the best examples of this ambiguity are Achilles and Agamemnon). This is also reflected in the description of their appearance, where individual heroes gain individual characteristics through comparison with others.

Nireus the handsomest man who ever came to Troy,

Of all the Achaeans after Peleus' fearless son,

But he was a lightweight, trailed by a tiny band.

(II 673-675; trans. Robert Fagles)

Such descriptions thus introduce a hierarchy among the heroes: one is better than another at something, but worse at something else. Achilles as the best of the Achaeans constitutes a kind of a template of a hero, which means that he outshines all others in every respect. The poet remarks that while Achilles withdrew from the fight and persisted in anger ( $\mu$ ńvıєv), the strongest of the Achaeans was Ajax, the son of Telamon (II 768-769). In further passages, Ajax is described as exceeding others in stature. ${ }^{21}$

In the case of other heroes, Homer may highlight either one splendorous quality, or a lack of one which makes the hero inferior - sometimes, however, it may be indicated that this lack is compensated for by an advantage. Defects and deviations from the template are not generally favorable. This is connected with the perception of beauty as a manifestation of value, and vice versa: ugliness is indicative of the worthlessness and even the harmfulness of a human being. This is most pronounced in the longest and most unique character description in the Iliad, the introduction of Thersites (II 212-224). He is deformed in every respect, and this goes hand in hand with the wickedness of his behavior. ${ }^{22}$ But a similarly negative evaluation of a character may also hide behind minor

${ }^{20}$ The Wedding of Smailagić Meho, by Avdo Medjedović, Serbo-Croatian Heroic Songs, vol. 3, trans. A. Lord, Cambridge (MA) 1974.

${ }^{21}$ Priam, when observing Achaean warriors from the city walls, sees him as standing out from the others (III 226-227): "Who's that other Achaean, so powerful, so well-built? / He towers over the Argives, his head, his massive shoulders!" (trans. R. Fagles). G.S. Kirk, op. cit., p. 297, notes that since, in Priam's opinion, Agamemnon was to stand out in terms of height, and Odysseus in terms of his broad shoulders, Ajax also surpasses them in these respects.

${ }^{22}$ K. Zieliński, Removing the Hunch or Thersites Re-appreciated, "Eos" 2004, no. 91, pp. 195-218, is of the opinion that this image of Thersites in the Iliad is influenced by what he has to say (a reprimand 
remarks. Ajax, the son of Oileus, is depicted as smaller than his namesake (II 528-529). This may be related to the perception of this character in the tradition as a wicked and vicious man who leads to the collective disaster of the Achaeans (in the cyclic tradition, the rape of Kassandra incurred Athena's wrath).

Homer skillfully uses the metonymic connection of the descriptive elements with their tradition-bound meanings, and by switching between the two, he obtains a sort of individuality of the characters. The purpose of this technique is to suggest the moral attitudes of the heroes. The poet thus achieves the effect of escaping simple assessments: the beauty of Paris, who goes into combat devoid of strength and courage, proves to be illusory. This scene is linked with the idea of Paris as guilty of suffering and of the final defeat of the Trojans. It should be noted, however, that such a view is suggested consistently, although rather allusively, as it is intertwined with the idea of Paris as a brave warrior. This picture is far from the unambiguously pejorative portrayal of Rakshasa Ravana in Ramayana, for example. This ambiguity in the depiction of Paris, which sometimes retains heroic elements and sometimes loses them, most probably results from the impossibility of separating this character from a tradition in which his actions did not necessarily have to be pejoratively labeled. ${ }^{23}$ In the Iliad, this pejorative interpretation is strengthened when Paris is contrasted with the particularly positive image of his brother Hector, a character probably absent from the earlier epic tradition. ${ }^{24}$ Appearance is thus inherently associated with the role attributed to the character by the singer, and with the moral interpretation of the events that make up the song in the singer's interpretation.

\section{Description of Odysseus}

The image of Odysseus which appears in Homeric poems seems to diverge from the pattern to which the other heroes conform. The inspiration and starting point for my analysis was the chapter from William B. Stanford's The Ulysses Theme (1955) entitled "The Untypical Hero." ${ }^{25}$ This untypical hero is precisely Odysseus. In fact, in Homer, Odysseus possesses all the traits of the hero: royal origin, good stature, strength, the necessary skill for battle and sporting competition, courage, energy, and eloquence.

and call for disobedience), which is associated with the iambic poet's ugliness (the ugliness of the iambic poet is paradoxical, because it is the poet's reprimand that creates a caricature of the reprimanded characters; however, it is a projection of the group's fears towards someone so dangerous that, despite acting in the interest of the community, he stigmatizes immoral behaviors, and threatens everyone individually).

${ }^{23}$ Kidnapping a woman, even someone's wife, in order to marry her does not have to be considered immoral at all. In the eyes of Homer, however, what discredits Paris is the violation of the rule of hospitality. He thus commits the gravest "sin" possible, which must result in changes in his image. The significance of behaviors associated with hospitality and moral evaluation of a character based on this category, see: S. Reece, The Stranger's Welcome, Ann Arbor 1993.

${ }^{24}$ This issue has been addressed numerous times in the literature, being most strongly emphasized in the works of neoanalysts: see W. Kullmann, Die Quellen der Ilias (Troischer Sagenkreis), "Hermes" 1960, no. 14 .

${ }^{25}$ Citing based on Homer. A Collection of Critical Essays, G. Steiner, R. Fagles (eds.), Engelwood Cliffs (NY), 1962. 
In contrast to this, many descriptions of Odysseus are found in later literature and philosophy where he is shown in a caricatured fashion: rotund with a pug nose, and in Lycophron (Alexandra $1242 \mathrm{ff}$.) he is even suggested as being a dwarf. ${ }^{26}$ Stanford undertakes to show that this image is the effect of the interpretation of certain Homeric phrases, interpretation influenced by the character's inclusion in comedies and by philosophical criticism.

Odysseus's short height is commented on in The Teichoscopia (III 191-224). Priam asks Helen: who is the warrior shorter than Agamemnon by a head, but broader in the shoulders? He also compares Odysseus to a ram that leads its flock, as he runs sprightly among the ranks of his soldiers. Helen, when introducing Odysseus, emphasizes that he knows "all tricks and cunning plans." Antenor confirms this by recalling how he had hosted Menelaus and Odysseus, the two ambassadors to Troy. At the Trojan congregation of the nation, when they stood next to each other, Menelaus surpassed him in height, but when they sat down, Odysseus looked more dignified. Antenor praises Menelaus's way of speaking, but in comparison Odysseus turns out to be a master speaker. Odysseus first stands staring at the ground and does not move the scepter, that is, he does not make any gestures, which suggests the attitude of someone who is resentful, or stupid, unable to speak. However, when he begins to speak, his voice is mighty and his words fall like snowflakes, so as we can infer from this comparison there was a profusion of words; the softness of falling snowflakes suggests fluency and effortlessly smooth speech. No mortal could compare with him. Finally, Antenor states that Odysseus's appearance should no longer influence the evaluation of this person: "Seeing [him] then, we would not be astounded by his appearance" (III 224).

In this description, Odysseus is not only short but also disproportionate (in this manner, for instance, demoniacal rakshasas are pictured in the Indian tradition). The characters in the story, however, try not to pay attention to this, or may even explain the irrelevance of this feature in light of other assets that qualify him as a hero. Stanford sees this matter a bit differently. First, he rejects Petroni's suggestion ${ }^{27}$ that Odysseus might represent someone of a different ethnicity, from the pre-Greek population, and then states: "The physical difference serves to mark Odysseus out as exceptional, without giving an impression of ugliness, oddity, or deformity." ${ }^{28}$ Odysseus is depicted as small among the giants, by way of comparison to Napoleon and the hero of the Old Irish Cuchulain, “'a short, dark man,' among the taller champions of the Red Branch Knights." ${ }^{29}$

Odysseus is the only one of all the heroes who talks about food and drink. In verbal jousting with Achilles, who demands to immediately attack the enemy and avenge Patroclus, he pleads on behalf of the tired and hungry army (XIX 155-172). Stanford rightly discerns here the voice of reason. However, he tries to interpret the

${ }^{26} \dot{\text { o }}$ võvo "a dwarf, having too small limbs in relation to the torso" (LSJ Greek-English Lexicon, s.v.).

${ }^{27}$ Unfortunately, I did not manage to access that publication.

${ }^{28}$ W.B. Stanford, The Untypical Hero, [in:] Homer. A Collection of Critical Essays, G. Steiner, R. Fagles (eds.), Engelwood Cliffs (NY), 1962, p. 124.

${ }^{29}$ Ibidem. 
scene when Odysseus was accused of cowardice in a similar manner. In his opinion, Odysseus's behavior is misconstrued when he escapes in a chaotic frenzy with the rest of the army and does not respond to Diomedes' appeal for support in his effort to save Nestor (VIII 92-98). ${ }^{30}$ Later, no one holds a grudge against Odysseus, not even Diomedes, who was abandoned on the battlefield. Similarly, the references to Odysseus's gluttony are, according to Stanford, misinterpreted words taken out of context. Agamemnon rebukes Odysseus for not being zealous to fight but the first to feast, together with the Athenian Menestheus (IV 343-346). Odysseus, after this reproof, goes eagerly into battle, passing over the comment about his gluttony in silence. The allegations of greed and gluttony originate, according to Stanford, in numerous comments Odysseus makes in the Odyssey, where he mentions the dictates of the "cursed stomach." In his opinion, Odysseus's greediness is fully justified by exceptional circumstances: he is the only one of the Achaean heroes who experiences hunger and then acts as a beggar. Stanford points out that even in times of hunger the hero could control himself and did not make the mistake of being lured into eating the lotus fruits or the meat from Helios's oxen. The philosophers (including Plato) thought less of him for producing a eulogy of feasting, when hosted by Alcinous, and calling it "what is best" (such meaning was then ascribed to the noun $\tau \dot{\varepsilon} \lambda \mathrm{o} \varsigma$ ) instead of providing the expected speech which was supposed to glorify moral virtues. Let us note here that this argument is amiss. Odysseus's statement is here a type of priamel, a rhetorical device used in poetic games at Greek feasts, where each man successively spoke on a particular subject to compete with other participants in the feast. A frequent "theme" was to praise what everyone considers to be the best in some respect. ${ }^{31}$ For Odysseus, feasting is a sign of social harmony. Hence, Plato assigns more importance to Homer's text than it originally possessed, and expects the Odyssey, a work intended to educate young people, to include moral principles expressed in gnomic form.

In conclusion, Stanford notices the difference between the traditional image of a hero and the Homeric image. ${ }^{32}$ He understands this traditional image, however, as a uniform ideal of the chivalric ethos: the hero's qualities are courage, boldness, and disregard for consequences and limitations. In his opinion, the image of Odysseus, which is a Homeric representation of the Ionian spirit, is innovative. Odysseus is characterized by reason and responsibility, but also by a thirst for knowledge and curiosity of the world, combined with self-interest. ${ }^{33}$ The descriptions of his meeting with the Cyclops Polyphemus and the Sirens may serve as an example of the latter features. As Stanford claims:

${ }^{30}$ Diomedes shouts: "where are you flying to, with your back turned like a coward?" (VIII 94).

${ }^{31}$ D. Collins, Master of the Game: Competition and Performance in Greek Poetry, Cambridge (MA) London, 2004, pp. 63-163.

${ }^{32}$ W.B. Stanford, The Untypical Hero, op. cit., p. 132.

${ }^{33}$ The link between entrepreneurship and Odysseus's prudence with the description of Ionians is a false premise present in the research to this day. According to this, Odysseus is perceived as a "hero of new times." See: A. Kouklanakis, Thersites, Odysseus, and the Social Order, [in:] Nine Essays on Homer, M. Carlisle, O. Levaniouk (eds.), Lanham-Boulden-New York-London 1999, pp. 35-36: "Since Odysseus appears as an epic hero, he may well be a product of a historical transition in social values, a transition toward a set of values by which his quasi homo novus status is beginning to gain importance vis-à-vis an older tradition of the heroic standard based on nobility and physical prowess." 
He himself asserts that his original motive for landing on the Cyclops's island was to see whether its unknown inhabitants were "violent, savage and lawless, or else hospitable men with god-fearing mind" - almost as if, in modern terms, he wanted do some anthropological research. It is more the motive of a Malinowski approaching the Trobriand Islands, than of a pirate or a conquistador. ${ }^{34}$

Stanford also analyzes the specificity of Odysseus's rhetoric, which in his opinion consisted in his fluency of speech, his lack of emotion and the adaptation of his speech to persuasive purposes ("Odysseus's speeches are strictly functional, as a rule"). ${ }^{35} \mathrm{He}$ argues that:

The general effect, we are told, was overwhelming. Homer corroborates this impression in several scenes in the Odyssey, where he describes how Odysseus could hold an audience spellbound "like a skilled bard." Homer could hardly have paid a higher tribute to his oratory. Once again he identifies Odysseus's powers with his own. ${ }^{36}$

Other features of Odysseus's image also contribute to his uniqueness: the use of the bow, a non-heroic weapon; the mention of poisoned arrows; the information about the grandfather-thief Autolycus; the contrast in the color of his hair: blond hair ( $\xi \alpha \dot{v} \theta 0 \varsigma)$ ), but probably a dark beard (Eustathius ad vi 250 and xvi 176); and his penetrating, lively look (iv 150-151). Thanks to the specific look of the boy Helen recognizes the similarity of Telemachus to his father and under her influence her husband Menelaus sees a striking resemblance:

His hands and feet are just like Ulysses';

so is his hair, with the shape of his head

and the expression of his eyes.

(trans. Samuel Butler)

Strong thighs, broad shoulders and chest, and strong arms (XVIII 67-69) may be the typical emblems of a hero, but Telemachus' feet and hands are unique and highly characteristic: they are just like Odysseus's. Helen is shocked: she could not confuse such limbs with those of another, and the same for his glancing eyes (IV 140-146). In the Il$i a d$, however, as we have seen, the discrepancy between these heroic traits and the nonheroic height was offset by Homer's remarks that Odysseus's shortness is unnoticeable in a sitting position. The comparison of Odysseus to a ram leading a flock probably performed a similar function of smoothing out this discrepancy, which steered the audience towards a non-heroic interpretation of this character.

The first problem here is how we do philology. Stanford critically analyzes abundant testimonies from different eras and ancient works, showing that their credibility is untrustworthy, because they are based only on Homer's text which they misinterpret in one way or another. First of all, ancient authors did not take into account the contexts in which certain statements and descriptions occurred. When we refine literary messages, we purify them of biased or rash allegations, and the goal is to extract what

\footnotetext{
${ }^{34}$ W.B. Stanford, The Untypical Hero, op. cit., p. 133.

${ }^{35}$ Ibidem, p. 128.

${ }^{36}$ Ibidem, p. 129.
} 
Homer really meant when he portrayed his character in a certain way. This approach is distinctive of classical philology, and it is often received with esteem and admiration. However, this may lead to highly unreasonable conclusions, one example being Welcker's and Wilamowitz's attempts at clearing Sappho's reputation of the accusations of pederasty and prostitution, which Denys Page protested only in 1955, showing that in research we must not apply a priori assumptions which reflect the researchers' sense of morality. ${ }^{37}$

Stanford also oversimplifies the matter and presents it in accordance with the knowledge of his age: all information contained in testimonies constitutes a later tradition based on Homer and distorts it, so only Homer is original. Indeed, it is assumed that there was some earlier tradition, but it must have been simple, stereotypical, and limited to one model of the heroic ethos. This way of thinking does not yet account for studies on oral culture and does not take advantage of comparative research. Let us go over the typical and distinctive features of Odysseus in the broader context of oral literature and comparative studies.

\section{Changes within tradition}

Both the author of the Iliad and the author of the Odyssey - unless it is the same person, of course - try to represent Odysseus in such a way that his role is equivalent to that typical of a hero. This is most evident in the Odyssey, where Odysseus is in many ways represented as no worse than Achilles and as ultimately surpassing him as the "real" conqueror of Troy. This applies especially to the possibility of using strength, extraordinary heroic strength. Achilles is the one who has Bín "the strength to fight," while Odysseus is equipped with $\mu \tilde{\eta} \tau 1 \varsigma$ "hidden thought" and $\delta$ '́ $\lambda$ o $\varsigma$ "cunning." ${ }^{38}$ In crucial moments, the narrative is carried out in such a way that Odysseus demonstrates "the strength to fight" and this is done in such a way that his role is not contrasted with Achilles's, but the opposite is true: the two heroes are equals. If something should be regarded as a traditional element, it is Odysseus's cunning and cleverness, whereas the secondary element is his heroic attributes, analogous to Achilles's heroism, and possibly Homer's individual literary choice (Eustathius calls him philodysseus, but the admiration for intelligence, which distinguishes this hero, leads to the transformation of his image so that he does not stand out from typical heroes: he is strong like Achilles, his presence under Troy is equally indispensable, but he cannot be "stupid" like Tale of Orašac or other allomorphs of this character (e.g., in American Indian tales).

What Odysseus has in common with the traditional template of a trickster is not only his blood relation to his grandfather, Autolycus, or to Sisyphus, whose descendant he was also supposed to be in other versions of the story (they both act as prototypes

${ }^{37}$ D. Page, Sappho and Alcaeus: An Introduction to the Study of Ancient Lesbian Poetry, Oxford 1955.

${ }^{38} \mathrm{G}$. Nagy suggests the conflict between these heroes who represent different modes of conduct in the tradition, op. cit., pp. 42-58. 
of thieves and cheats), ${ }^{39}$ but also other stories collected in the so-called Cyclic Poems, which certainly cannot be judged today as only later works wherein Odysseus is characterized by perversity, deceitfulness, envy, and greed often directed against his own kin: he feigns madness to avoid going to war, he kills Palamedes, he steals the palladium, and he takes credit for others' merits and achievements (bringing Anios's daughters instead of Palamedes; taking the palladium and discrediting Diomedes; taking Achilles' armor at Ajax's expense; and taking possession of Philoctetes's bow without his consent). These appropriations can be classified as theft because they represent illegal or perhaps illegitimate acquisition of these artefacts. Homer, like any oral composer, cannot cut ties with this tradition, and he cannot change it. $\mathrm{He}$ can, however, provide his own interpretation. Subsequent explanations try to cancel out the traditional interpretation of images, replacing them with new ones. "New" does not mean non-traditional or located outside of tradition. It is a typical transmission of the same traditional material with the ever-changing understanding of it. The power of inertia of this traditional message is so strong that despite the enormous influence of Homer's poems on Greek culture, the traditional roles of the heroes were still perceived in the same way. This is evident in the portrait of Odysseus utilized in the Attic tragedy: he is insidious, selfish, and baleful to his own kin.

\section{The accusation of greed (voracity)}

The question of whether Achilles was driven by heroism or stupidity when he contended with Odysseus about sending him straightaway into battle and demanding that he forsakes food, is the result of two overlapping models of interpretation of the Homeric narrative. The reason behind Achilles renouncing a meal is the plot being constructed in harmony with the ritual order that governs this reality, which is much more important than Odysseus's rationality. Richard Seaford shows how refusing food is associated with one's inability to come to terms with the death of a loved one and must be extended until the completion of the ritual of reciprocation. ${ }^{40}$ Achilles could not have done things differently. The poet, however, collides this heroic need with anti-heroic pragmatism. Therefore, Odysseus's words could have suggested the leading of the protagonist into temptation, which is a trickster-like activity where the hero is stripped of his glory, making it impossible for him to act. The conflict is representative of the oral epic in which someone tries to reprimand the hero in order to deprive him of his glory. A case in point is the admonishment which Beowulf hears

${ }^{39}$ I want to thank the anonymous reviewer to draw my attention to P. Philippson, Die vorhomerische und die homerische Gestalt des Odysseus, „Museum Helveticum” 1947, no. 4, pp. 8-22, where a similar kind of thinking is presented: in the pre-Homeric tradition Odysseus was linked instead with Hermes (this god was also recognized as a trickster figure), and only Homer gave this character heroic features (a hero of Athena).

${ }^{40}$ R. Seaford, Reciprocity and Ritual: Homer and Tragedy in the Developing City-State, Oxford 1994, pp. 159-166. 
from Unferth ${ }^{41}$ - a malicious, crafty vassal to Hrothgar - when he arrives at Heoroth. He speaks of Beowulf's heroic deeds as a senseless end to life, hence useless and stupid. Beowulf "rescues" his fame by praising himself. Likewise, Arjuna salvages his honor with self-praise after the unjust reprimand of his brother, Yudhishthira. Exposing the soundness of pragmatic thinking in the Iliad overshadowed that traditional and ritual meaning. One could assume that in a parallel version of the story, Achilles's refusal of food in this situation could signify his victorious completion of the test to which he was subjected.

Gluttony is a metaphor for the gravest accusation that can be levelled within the moral code of an iambic rebuke, as this is the kind of greed that leads to reaching for a neighbors' goods. ${ }^{42}$ "Rotund, fat" is a typical insult in castigatory verse, as it condemns a rapacious person, meaning a man reaching for that which does not belong to him, and hurting others at the same time. In iambic poetry, greed does not do the greedy person any good; paradoxically, under its influence, he languishes away, loses weight or loses his strength, a symptom of which can also be a large belly. The Odyssey portrays the greed of the suitors, and that greed is the cause of their perdition: all their vice is derivative of it. Thus, the hero who must eliminate them and restore the social order cannot have the same fundamental flaw. His purgation is necessary. By shifting the burden from the voraciousness of his "cursed stomach" to the extreme circumstances that incline him to certain behaviors, Homer reinterprets the traditional material. The unrestrained appetite of a character, which is ridiculed in castigatory poetry (also paradoxically symptomatic of its composer, an iambic poet) is replaced here by humiliating hunger (asking someone for help signifies a helpless attitude and giving up an equal position in the hierarchy). The blade of derision was blunted, but the grotesqueness of this attitude was not fully eliminated, as evidenced by the reactions of the ancients, which were mentioned by Stanford.

\section{The comparative perspective}

Features that are attributed to Odysseus are also found in descriptions of other atypical heroes of other epic traditions. Let us limit ourselves to two examples:

1) the mythological hero of the Ulster cycle, Cúchulainn, already mentioned by Stanford. The name means "Culann's Hound," because after he had killed a monstrous guard dog, he offered to take its place. The nickname "killer of the dog-monster" links him with Hermes, nicknamed "the killer of the dog Argos,"

${ }^{41}$ His name is significant and means "Un-peace, Quarrel" (J.R.R. Tolkien, Beowulf. A Translation and Commentary, London 2014, p. 288; M. Opalińska, The (Un)known "Beowulf" - Walking Through the Shadows of an Old English Epic, "Kwartalnik Neofilologiczny" 2016, no. 63/3, corroborates this, p. 277.)

${ }^{42}$ It is not an offense to reach for a wife or goods of a stranger, especially that of an enemy. On the other hand, the problem is getting rich at the expense of your own kin, or even envy which may lead to this. This corresponds to the 9th and the 10th commandments, which also originally referred to the members of the same nation. 
a character interpreted as a trickster. ${ }^{43}$ The appearance of the old-Irish hero is a juxtaposition of contrasts, emblematic for a trickster: like any hero-protagonist, he is beautiful and young (his boyish age is emphasized by the term "without a beard," which might also be applied to Achilles). Paradoxically, however, he is short. In The Wooing of Emer and in Bricriu's Feast, we read: "a dark, sad man, comeliest of the men of Erin"; in Intoxication of the Ulstermen, a "little, black-browed man"; in Phantom Chariot of Cú Chulainn "his hair was thick and black, and as if he had licked it... in his head his eyes gleamed swift and gray." ${ }^{44}$

2) Alyosha Popovich, one of the three bogatyrs - or heroes of the bylinas (East Slavic medieval epic poems) along with Ilya Muromets and Dobrynia Nikitich - is not a man of prowess; sometimes it is even his weakness or disability that is highlighted (he is lame). He is characterized by his virility, spontaneity, and the quickness of his gaze and thoughts, which allows him to find a way out of every situation, but also by cunning and treachery (especially visible in his "piercing, clever little eyes"). His negative features are often revealed: he is perfidious and two-faced; he is a braggart, a vainglorious, deceitful, and lying man (one day he says one thing, and the next day another). His jokes elicit laughter, but they can also bring evil upon his people. Sometimes his actions are met with the disapproval and condemnation of the other heroes. Sometimes it turns out that he knows how to play the gusle.

As well, this last skill brings him closer to Odysseus, who perhaps is not shown as a singer, but the researchers identify a series of allusions in The Odyssey that may link Odysseus's behavior with the performance of songs. ${ }^{45}$

\section{Odysseus the trickster}

The portrayal of Odysseus in the Odyssey is paralleled by the portrayal of Hephaestus in the song of Demodocus (VIII 266-366) as a lame god who uses art and magic, and

${ }^{43}$ In this volume, Szyjewski outlines the interpretations W.B. Kristensen and J.P.B. de Josselin de Jong of Hermes as a trickster figure.

${ }^{44}$ The witch (prophetess) Fedelm describes him in Táin Bó Cúailnge as blond, and in the further sections of this song there appears a more detailed description:

"And certainly the youth Cúchulainn mac Sualdaim was handsome as he came to show his form to the armies. You would think he had three distinct heads of hair - brown at the base, blood-red in the middle, and a crown of golden yellow. This hair was settled strikingly into three coils on the cleft at the back of his head. Each long loose-flowing strand hung down in shining splendour over his shoulders, deep-gold and beautiful and fine as a thread of gold. A hundred neat red-gold curls shone darkly on his neck, and his head was covered with a hundred crimson threads matted with gems. He had four dimples in each cheek - yellow, green, crimson and blue - and seven bright pupils, eye-jewels, in each kingly eye. Each foot had seven toes and each hand seven fingers, the nails with the grip of a hawk's claw or a gryphon's clench" (The Táin, trans. T. Kinsella, Oxford 1969, pp. 156-158).

${ }^{45}$ Analogous to the story of Demodocus, as well as Phemius, there is an extensive story about his return, which was presented to the Phaiacians. Some comparisons correlate with this suggestion, e.g., when Odysseus draws the bowstring as skillfully as a singer pulls the cithara string (XXI 405-411). 
who defeats Ares by means of subterfuge. This parallel seems to communicate a situation best known from Aesop's fables, in which someone inherently weaker proves to be stronger than their persecutor. This wisdom takes many versions and is adapted in oral culture to specific circumstances, serving as a warning: "watch out, do not act this way, because someone you do not suspect of being capable of retribution is, in fact, capable of it." In the fables, this vengeance is achieved thanks to an extraordinary ability of the individual subjected to oppression, thanks to an extraordinary friend, or thanks to an appeal to the final instance, or a god who guarantees justice (dike) through exacting revenge, so everyone gets what they deserve (their hybris which harms other members of the community is punished or tamed). Odysseus is such an unassuming hero. Surprisingly for his enemies, it turns out that his intellectual acumen can get him out of trouble. This, however, means, at the same time bringing disaster or destruction to others. ${ }^{46}$

This particular ambivalence of Odysseus (he is simultaneously weak and strong) is revealed in the etymology of his name, as suggested by Homer. This name was supposed to be given to him by his maternal grandfather, Autolykos, and derive from the hypothetical verb odyssomai (in reality, the name is certainly of a non-Greek origin): the protagonist was supposed to be a man who brings hatred by wreaking revenge, and, at the same time (as Stanford showed) to be a "man doomed to odium." G.E. Dimock went a step further by suggesting that the name Odysseus should be understood as "trouble," because he both causes trouble to others and runs into trouble himself. Dimock demonstrates a constant regularity: when Odysseus abstains from performing a deed, this causes him suffering and loss of fame, so he risks sinking into oblivion, and, by the same token, losing his heroic status, whereas when he decides to perform the deed he brings suffering to his enemies, at the same time ensuring immortal fame for himself. ${ }^{48}$ Norman Austin observed that even those close to Odysseus, like Penelope, Telemachus, and Eumaeus avoid mentioning his name in his absence. The researcher explains that this is caused by the fear of uttering

46 This ability is marked by distinctive epithets for Odysseus. Polutropos means "one who knows many ways" to - implicitly - get out of a difficult situation. K. Zieliński (Zmiany znaczenia komunikatu w przejściu od kultury oralnej do piśmienniczej w warunkach Grecji archaicznej, [in:] Historia idei komunikacji, M. Wendland (ed.), Poznań 2015, pp. 277-304) notes that in oral culture this means not so much inventiveness as the conviction that there are many ways to deal with problems - and awareness of them is awareness of tradition. Intelligence is understood as the ability to apply tradition in practice. This does not mean that the actions of Odysseus or other people like him are devoid of inventiveness, but that this inventiveness is imperceptible. This is true for the skills of epic singers such as Demodocus: their songs cannot be understood in terms of innovation (autoschediasmata) or knowledge of a certain number of songs identified with tradition. Demodocus knows the tradition that he can convey in episodes. This means that a particular episode may be invented, but it must be based on traditional patterns and combined with a known tradition in a conventional way (see K. Zieliński, Iliada i jej tradycja..., op. cit., pp. 97-121). The epithet polumêtis stands for knowing of many ways to harm someone (mētis means "hidden thought, cunning intelligence," a thought that is hidden behind some action, so other people do not realize that the actions taken by the protagonist are to bring a different result than expected, see: G. Nagy, op. cit., pp. 45-49). These two epithets thus reflect the two aspects of the hero's conduct as contained in the epic code: the ability to rescue oneself from trouble and simultaneously harm one's enemies.

${ }^{47}$ W.B. Stanford, The Homeric Etymology of the Name Odysseus, "Classical Philology" 1952, vol. 47, pp. 209-213.

${ }^{48}$ G.E. Dimock Jr., The Name of Odysseus, "The Hudson Review” 1956, vol. 9, p. 64. 
an ominous word that brings misfortune on others, and perhaps also on oneself. ${ }^{49}$ Odysseus disadvantages himself by uttering his name to the wounded Cyclops (he incurs Polyphemus's curse on himself), but saying his name is also a necessary condition for warranting his heroic glory (e.g., he gives his name to the Phaeacians before describing the magnitude of his achievements, and introduces himself to the suitors in the same way just before exacting his revenge). In the first case, the author of the Odyssey suggests interpreting self-praise as morally reprehensible bragging, whereas the subsequent disclosures of Odysseus's identity play an important role in perpetuating the fame of the hero. This latter circumstance is characteristic of the oral epic: the hero's boasting is not negatively evaluated; on the contrary, it is indispensable for the hero to retain his fame (just like the self-praising of Beowulf and Arjuna mentioned above). An interpretation of this motif as morally disgraceful is, however, equally possible.

This incongruity of meanings is one of the ways in which the singer (the author of an epic story) tantalizes listeners as he tries to capture and maintain their attention in every way. The same element can be evaluated differently at different times. The magical ambivalence of the hero's name is tied to the ambivalence of the hero himself who, despite playing the role of a protagonist, remains dangerous through and through, not only to enemies, but also to his own kin. Gregory Nagy identifies a similar link between the ambivalence of the hero's name and the conduct of the hero in the case of Achilles, whose name he derives from the noun akhos, which means, "sadness, unhappiness, sorrow." Achilles plays the same part in tradition every time: by refraining from combat, he brings akhos to his men; when he goes into battle, he inflicts akhos on the enemies. ${ }^{50}$ The hero is a beneficial, if not dangerous, figure for his own kin as well. ${ }^{51}$ The ambivalence of the consequences of his behavior corresponds to the ambivalence of the trickster's behavior. Both characters, the hero and his malicious antagonist who tries to challenge the hero's glory, influence each other. As a result, we cannot make a clear-cut division into the beneficial action of one and the harmful actions of the other.

According to Gregory Nagy, within the oral tradition of the Trojan cycle, Odysseus is involved in conflict with Achilles. ${ }^{52}$ Odysseus somehow steals the feat of conquering Troy from Achilles. The motif of a hero's sacrifice for some communal goal (Achilles's death), compulsory in the epic tradition (though not expressed directly in the Iliad), thanks to which Achilles is treated as the "conqueror of the city," has been interpreted as failure to achieve the goal, which would be possible only through the use of a different tactic: non-heroic action, or deception. Here an opportunity pre-

${ }_{49}$ N. Austin, Name Magic in the Odyssey, "Classical Antiquity" 1972, vol. 5, pp. 1-19.

${ }^{50}$ G. Nagy, op. cit., pp. 69-93.

${ }^{51}$ There may be different understandings of this motif in individual epic traditions. Cúchulainn is so ardent in the fight that he kills all who stand in his way, not recognizing his own kin, in a bout of rage. This is a sort of rationalization of the motif that originally had connotations with magic, which seems to be indicated by the danger associated with the names of Odysseus and Achilles. However, the resemblance to the figure of Cúchulainn is striking. The Irish hero is also dangerous, both to his enemies and his fellows and countrymen.

${ }^{52}$ G. Nagy, op. cit., pp. 42-58. 
sented itself to use a beneficial effect of Odysseus-trickster. This idea must precede the Odyssey known to us, but it is subjected to a further reinterpretation resulting in the strenuous efforts to depict Odysseus as a hero exhibiting strength capable of defeating enemies, comparable to the strength $(b i \bar{e})$ of Achilles.

The slyness attributed to this character also seems to sparkle in the hero's eyes, analogous to the piercing and cunning eyes of Alyosha Popovich. Helen, recognizing the similarity of Telemachus to her father, draws attention to the boy's sharp look, just like Odysseus's. In this scene, Telemachus demonstrates the ability to behave properly as a guest and to curry favor with Menelaus. If we take into account the impact of an epic poem on the audience, it means that the character will win approval from the listeners of Homer's tale: the young hero abides by the principles of moral behavior shared by the public. From the perspective of tradition, he proves to be worthy of joining the ranks of heroes (this is, therefore, an element of initiation of a young hero). We can explain the need to show the young protagonist in such a light by the reinterpretation of the eyes of Odysseus, traditionally associated with cunning understood as quick wits and lively intelligence. Indirect proof of this may be the scene in the Iliad in which Odysseus is looking at the ground as he speaks: is he perhaps hiding his eyes? Odysseus may not want to reveal his true nature. This must remain a hypothesis, but in the scene in which ambassadors come to Achilles's tent, he responds to the speech of Odysseus, stating that he detests people who say different things than they think (IX 312-313). We cannot be sure whether he means Agamemnon or Odysseus, or maybe both of them, and even the audience of the epic tale could have experienced such ambivalence.

\section{Conclusion}

Two issues seem to be most important. Two modes of behavior are crucial, and it is the selfish mode, resulting from the individual need to ensure survival, that seems to be originally associated with trickster-type characters. Selfish deeds, however, can sometimes benefit the group, even if it was not the primary motive of such an individual. In an epic tale, the trickster figure plays the role of antagonist to the protagonist-hero. The basic difference between these characters is the hero's ability to sacrifice himself for the good of the group, or its survival.

The second important issue is the necessity to analyze oral culture as a dynamic structure, one subject to constant changes. The purpose of the narrative influences the distribution of features to individual characters and the interpretation of their roles in the composition.

\section{References}

Adkins A.W.H., Merit and Responsibility, Oxford 1960.

Austin N., Name Magic in the Odyssey, "Classical Antiquity" 1972, no. 5, pp. 1-19. 
Cairns D., Oxford Readings in Homer's Iliad, Oxford 2001.

Collins D., Master of the Game: Competition and Performance in Greek Poetry, Cambridge (MA) London (England), 2004.

Dawkins R., The Selfish Gene, Oxford 1976.

Dawkins R., The God Delusion, London et al. 2006.

Dimock Jr. G.E., The Name of Odysseus, “The Hudson Review” 1956, no. 9, pp. 52-70.

Douglas M., Purity and Danger. An Analysis of Concepts of Pollution and Taboo, London 2001.

Foley J.M., Immanent Art: From Structure to Meaning in Traditional Oral Epic, Bloomington (IN) 1991.

Foley J.M., The Singer of Tales in Performance, Bloomington-Indianapolis 1995.

Gould J., Myth, Ritual Memory, and Exchange. Essays in Greek Literature and Culture, Oxford 2001. Griffin J., Homer on Life and Death, Oxford 1980.

Griffin J., The Speeches, [in:] The Cambridge Companion to Homer, R. Fowler (ed.), Cambridge 2004, pp. 156-167.

Homer. A Collection of Critical Essays, G. Steiner, R. Fagles (eds.), Engelwood Cliffs (NY), 1962.

Kirk G.S., The Iliad: A Commentary, vol. I: books 1-4, Cambridge 1985.

Kouklanakis A., Thersites, Odysseus, and the Social Order, [in:] Nine Essays on Homer, M. Carlisle, O. Levaniouk (eds.), Lanham-Boulden-New York-London 1999, pp. 35-36.

Kullmann W., Die Quellen der Ilias (Troischer Sagenkreis), "Hermes," no. 14, Wiesbaden 1960.

Meletinsky E., Pochodzenie eposu bohaterskiego. Wczesne formy i archaiczne zabytki, Kraków 2009 (Proiskhozhdenye geroitsheskogo eposa, Moscow 1963).

Nagy G., The Best of Achaeans: Concepts of the Hero in Archaic Greek Poetry, revised edition, Baltimore-London 1999.

Opalińska M., The (Un)known "Beowulf" - Walking Through the Shadows of an Old English Epic, "Kwartalnik Neofilologiczny" 2016, no. 63/3.

Page D., Sappho and Alcaeus: An Introduction to the Study of Ancient Lesbian Poetry, Oxford 1955.

Philippson P., Die vorhomerische und die homerische Gestalt des Odysseus, „Museum Helveticum” 1947, no. 4, pp. 8-22.

Reece S., The Stranger's Welcome, Ann Arbor 1993.

Reciprocity in Ancient Greece, C. Gill, N. Postlethwaite and R. Seaford (eds.), Oxford 1998.

Schofield M., Euboulia in the Iliad, "Classical Quarterly" 1986, no. 36, pp. 6-31.

Scodel R., Listening to Homer: Tradition, Narrative, and Audience, Ann Arbor (MI) 2002.

Seaford R., Reciprocity and Ritual, Homer and Tragedy in the Developing City-State, Oxford 1994.

Slatkin L., The Power of Thetis: Allusion and Interpretation in the Iliad, Berkeley 1991.

Stanford W.B., The Homeric Etymology of the Name Odysseus, "Classical Philology" 1952, no. 47, pp. 209-213.

Stanford W.B., The Ulysses Theme. A Study in the Adaptability of a Traditional Hero, Oxford 1955.

Tolkien J.R.R., Beowulf. A Translation and Commentary, London 2014; citing based on Polish translation. Warszawa 2015.

The Wedding of Smailagić Meho, by Avdo Medjedović, Serbo-Croatian Heroic Songs, vol. 3, Cambridge (MA) 1974.

Wees H. van, Status Warriors, War, Violence and Society in Homer and History, Amsterdam 1992.

Wees H. van, Greek Warfare: Myths and Realities, London 2004.

Wilson D.S., Darwin's Cathedral. Evolution, Religion, and the Nature of Society, Chicago-London 2002.

Zieliński K., Removing the Hunch or Thersites Re-appreciated, "Eos" 2004, no. 91, pp. 195-218.

Zieliński K., Iliad and Its Epic Tradition. A Study in Greek Oral Tradition, Wrocław 2014.

Zieliński K., Zmiany znaczenia komunikatu w przejściu od kultury oralnej do piśmienniczej w warunkach Grecji archaicznej, [in:] Historia idei komunikacji, M. Wendland (ed.), Poznań 2015, pp. 277-304. 
